\title{
KKF i 20 år - hvad skrev vi om?
}

\section{Af Karen Sjørup}

Missionarkvinder, delfinkvinder, prostituevede og prostitutionskunder, nationens døtre, velferdsstatens moder, akademias drag, vores fallos, trans, queer og skave kon er nogle af de fenomener, konstruktioner eller illusioner, som konsforskningen bar gransket gennem 20 àr. Essayet prøver at finde nogle linjer og udviklinger $i$ den analytiske omgang med disse. når jeg læser i KKF fra 1994, altså fra for 18 år siden, at de personer, som er opført som redaktionsgruppe, for størstedelens vedkommende stadig er at finde i vores redaktionspanel. Dengang var de ikke som nu opført med titel men derimod med fag, og der er tydeligt en tendens til overvægt af samfundsvidenskabelige og humanistiske fag, men samtidigt også repræsentanter fra medicin, fysik og ingeniørvidenskab.

Fem af redaktionsgruppen fra 1994's medlemmer har siden opnået et professorat, heraf de to i Sverige. I sig selv kan dette tale for, at kønsforskningen som forskningsområde på tværs af fag har opnået en vis form for akademisk anerkendelse. Men at denne langtfra er entydig anskueliggøres også ved, at der er en forholdsvis lille ny-rekruttering til emnet.

Samtidig kan man også konstatere, at mens KVINDER i de første år er skrevet med store spærrede typer, mens køn og forskning er skrevet med væsentlig mindre 
skrift, så er 'kvinder', 'køn' og 'forskning' siden årtusindeskiftet skrevet med samme typer, omend kvinder - og ikke mænd - er fastholdt i den lidt selvmodsigende modstilling af kvinder og køn.

Det er således også tydeligt, at mandeforskningen har fyldt relativt lidt i KKF over årene, måske er det stadig vanskeligt for mandeforskerne at identificere sig med ordet kvinder som det første i titlen på tidsskriftet. Eller også handler det ganske enkelt om, at der højest er en håndfuld forskere i Danmark, som identificerer sig som mandeforskerne. Derimod er 'queer', 'trans' og 'skæve køn' rykket ind i forsøget på analytisk og i den politiske praksis at opløse kønnenes stereotype binaritet.

Jeg har i det nedenstående ud fra et ikke særlig videnskabeligt princip, nemlig 'hvad tiltrak mit øje', forsøgt at opridse nogle linjer og tendenser i de 20 års kønsforskning, omend der kunne fremhæves væsentligt flere, for uanset at gruppen af kønsforskere ved universiteterne i Danmark er lille, så må man sige, at der er stor mangfoldighed i de emner, der tages op. Det afspejler jo også, at kønsforskningen, som Nina Lykke (2008: 33) har påpeget, på den ene side $\mathrm{i}$ meget høj grad har tilpasset sig både de enkelte discipliners teorier og metoder og tilegnet sig en tværvidenskabelig tilgang i et sådant omfang, at det har udviklet sig over en multividenskabelig tilgang, hvor "forskere fra enkelte videnskabsgrene i samarbejde kaster lys over kompleksiteten i køn, kønsmagtsordninger, kønsrelationer etc., men med opretholdelse af enkeltdisciplinernes teoretisk-metodiske udgangspunkter", til det man kan kalde en 'transvidenskab', hvor disciplingrænser ophæves helt (Lykke 2008: 34). Man må dog alligevel konstatere, at denne synergi-effekt kun delvis er opstået, og at kønsforskningen i nogen grad har tilegnet sig et teoretisk fællesskab men stadig opretholder metoder, der er knyttet til de enkelte fagdiscipliner.

\section{MISSIONÆRKVINDEN}

Den første artikel, som tiltrak mit øje i de tidlige udgaver, var at finde i det særlige julenummer fra 1994, som kun indeholder en artikel, nemlig "Jul på sømandsmissionen i Calcutta" af Karin Lützen (Lützen 1994).

Artiklen beskæftiger sig med en dansk tjenestepige, Andrea Gehlert, som i 1888 fik et kald om at redde karenerfolket i Indien og derfor, efter ophold på Askov Højskole og sygeplejeuddannelse på Diakonissestiftelsen, begav sig af sted til Calcutta, hvilket i sig selv var en kæmpebedrift for en kvinde af arbejderklassen på den tid. Imidlertid blev hun hurtigt optaget af at redde danske søfolk fra spiritus, hor og kønssygdomme ved at oprette læsestuer, hvor søfolkene kunne læse dansksprogede bøger og aviser og derfor ikke kastede sig ud i det syndige liv på værtshusene og bordellerne. En del af arbejdet bestod også $i$ at besøge kønssyge søfolk på hospitalerne og retlede dem til et fromt kristent liv.

I løbet af få år blev hun gift med en anden missionær og fik to børn. Børnene blev imidlertid sendt til Danmark, da de ikke tålte klimaet. Manden døde efter få år. Derefter fik hun unge højskoleelever ud som hjælpere, men de døde også ret hurtigt. Siden rejste hun til Sydamerika og de DanskVestindiske øer, og oprettede også her læsestuer og børnehjem. Først da hun var langt oppe i 70'erne vendte hun hjem.

Artiklen overvejer ikke de teoretiske aspekter ved denne form for udøvelse af en stærkt moralistisk form for kvindelighed, der med kristendommen som baggrund beskxftiger sig med søfolkenes moral og seksuelle afholdenhed snarere end med de prostituerede kvinders vilkår. Det er således en kvindelig heltehistorie, hvor den religiøst oplyste kristne kvinde rejser ud for at redde danske søfolk fra den lyst og synd, som den fremmede kvinde og de vantro repræsenterer. 


\section{SEXTURISTEN}

15 år senere bragte KKF et temanummer med titlen Sex til salg. I dette nummer skrev Mikkel Bang Fossum (Fossum 2001) en artikel om unge rygsækrejsende europæiske mænds $k ø b$ af sex på en thailandsk $\varnothing$.

Artiklen beretter om, hvorledes denne form for sexturisme ofte udvikler sig fra et tilsyneladende tilfældigt møde til et forhold, der for manden er en forelskelse, men som hurtigt udvikler sig til et økonomisk forhold $\mathrm{i}$ form af en forventning fra den thailandske kvindes side om gaver, tilskud til medicin til den gamle mor m.m., og siden et brevudvekslingsforhold, hvori der indgår løbende indbetalinger fra mandens side $\mathrm{i}$ forsøget på at fastholde forholdet og forsøge at få kvinden til Europa til giftermål og holde kvinden fri af prostitution. Nogle af kvinderne, som på deres side også spiller rollen som forelskede, kan holde adskillige forhold kørende på samme måde og dermed sikre sig en mere stabil indtægt ved siden af prostitutionen.

Artiklen fastholder billedet af den uskyldigt erotiksøgende mand, for hvem det globale økonomiske magtforhold bliver en form for tiende han må betale for den ubundne seksualitet. Samtidig afspejler den også vore etnocentriske forestillinger om den romantiske kærlighed og forelskelse som det naturlige udgangspunkt for et erotisk forhold og siden ægteskab.

Der indgår således ikke $\mathrm{i}$ artiklen nogen religiøs dom over denne adfærd, som i det forudgående eksempel, men de nævnte forhold indebærer dog alligevel en form for stempling, som vel generelt rammer mænd med asiatiske kvinder, vel ikke mindst fra feministisk hold, i og med mænds erotiske eskapader med 'fremmede' kvinder, fx Jørgen Leths kokkepiges datter, kan betragtes som en indirekte kritik af danske kvinders selvstændighed og voksenhed (Leth 2005; Johnsen 2005).

Temanummeret indeholder også en række andre artikler, som i højere grad ser kvinder som ofre i den stadigt mere internationale prostitution og trafficking, og $\mathrm{i}$ historisk sammenhæng den europæiske kvinde som offer for 'hvid slavehandel', men det er tankevækkende, at både missionæren og den mandlige forsker, ser de europæiske mænd som ofre for de 'andres' uciviliserede seksualitet.

\section{NATIONENS DØTRE}

I 1994 udkom også et nummer om køn, kultur og national identitet (1994/2). Heri har Anne Knudsen skrevet en artikel, "Forvandlede kroppe", som fremstiller nationalitet som en diskurs, som ofte ikke er så betydningsfuld for det liv, der faktisk leves, men som derimod er med til at skabe køn og anvende kvindekønnet som en synlig markør for det nationale, hvilket tilsvarende udelukker kvinder fra at fraternisere med de fremmede.

Nationalismen er sød, mens den er lille og hvis den kan smykke sig med historier om en fortid i kolonial undertrykkelse og racistisk udryddelse, så meget desto bedre. Men ingen sociale fællesskaber er "naturlige" og ingen sociale identiteter er "naturgroede". Enhver social identitet og enhver organisering af mennesker er konstrueret. Kønnet er konstrueret, barndommen er konstrueret, stammer og religiøse klaner er konstruerede (Knudsen 1994a: 10).

Anne Knudsen var således blandt de allerførste til at indtage en radikal socialkonstruktionistisk position i kønsforskningen.

Et tilsvarende billede af forholdet mellem køn og nation fremstilles historisk i Anette Warrings artikel "Kvinders kroppe" (Warring 1994) i samme nummer af KKF hvor tyskerpigerne og efterkrigstidens behandling af disse netop understreger kvinderne og ikke mindst deres seksualitets betydning for det, som måske kunne synes en sårbar national identitet. Således fastslår Knudsen også, at voldtægten er den ultima- 
tive besættelse af kroppe, mens tyskerpigernes lystfulde hengiven sig til tyske soldater yderligere ses som en hån mod den truede nationalisme.

Samtidig udtrykker Anne Knudsen også den radikale socialkonstruktivistiske tilgang som en af de første i dansk kønsforskning. Mens Anette Warring primært betjener sig af historiefagets dokumentaristiske og kildekritiske tilgang, tillagt solidaritet med og moralsk oprejsning for de danske kvinder, som i efterkrigstidens opgør kom til at repræsentere fjenden. Dermed er der også et emancipatorisk perspektiv i Anette Warrings tekst, som ellers synes at glide ud af kønsforskningen i disse år.

\section{DELFINPRINSESSEN}

I nummer 1995/2 skrev Nina Lykke og Mette Bryld artiklen "Delfinprinsesser og xdle vilde" (Lykke \& Bryld 1995), som jeg på mange måder ikke forstår, men som allerede på dette tidspunkt satte spørgsmålet om forholdet mellem køn og natur på dagsordenen, idet de fremhævede delfinen som en særlig æestetiseret udtryk i vores verden for ophævelsen af skellet mellem menneske og natur i videnskaben, og tilsvarende de mange hybrider mellem kultur og natur, som vi omgiver os med i form af fx reagensglasbefrugtning og regnskoven, der er forvandlet til museer.

Artiklen beskæftiger sig med delfinens nutidige rolle som en særlig glidningsfigur i spillet mellem køn-race-natur, som et pattedyr, der lever i vand, men ånder med lunger, føder levende unger og tillægges flydende kønsskifter og store komplekse hjerner. Samtidig har vi i delfinen genskabt billedet af den rdle vilde, som af naturen besidder gode og rigtige egenskaber, som betvivler civilisationens værdi. Kvinder, børn og bønder blev tidligere omfattet af forestillingen om den gode vilde, og tilsvarende er delfinen et udtryk for den ædle vilde med glidninger mellem delfinen og kvinden, mellem den kvindelige intuition og delfinens evne til at navigere ved hjælp af lydbølger. Således mener Lykke og Bryld at der i delfinprinsessen er et signal om, at der skabes nye ikoner for 'andethed', end de tidligere 'andre' representeret af kvinden og den xdle vilde:

(...) i det øjeblik, hvor feminismen har erklæret Kvinde for død og den hvide mands kolonialistiske drøm om den ædle vilde synes endeligt overhalet af verdenshistorien, så puster vores hvide delfinprinsesse liv i en ny serie tavst smilende, gådefulde, men først og fremmest gode hjxlpsomme healings-beredte 'andre' (Lykke \& Bryld 1995: 61).

\section{VELFÆRDSSTATENS MODER}

KKF 1994/3 er et temanummer om kønnets teorier. Her vil jeg navnlig hæfte mig ved to artikler, som på hver sin måde indvarsler nye tendenser i kønsforskningen på dette tidspunkt. Birte Siim skriver om kvinders medborgerskab og de forskellige opfattelser, der rådede om forholdet mellem køn og medborgerskab. På den ene side Carole Pateman, som opererede med den patriarkalske adskillelse mellem den 'private' familie og den 'offentlige' politiske arena og kvinders udelukkelse fra den offentlige politiske arena, med moderskabet som en central årsag til denne udelukkelse. På den anden side den 'maternalistiske' hypotese, som positiverer kvinders omsorgsorientering og dennes rolle $i$ opbygningen af den moderne velfærdsstat. Siim kritiserer denne hypotese for at den idealiserer kvinders rolle som mødre og undervurderer styrken af mandsdominansen i samfundet.

Endelig de feministiske pluralister, $\mathrm{fx}$ Phillips og Mouffe, som i højere grad opererer med mangfoldigheden i kvinders erfaringer, interesser og politiske praksis, og dermed også sociale, etniske og racemæssige forskelle i kvinders politiske praksis, og dermed også kvinders politiske mobilisering og radikalisering i den nye kvindebevægelse. Dermed er idealet også et pluralistisk og 
differentieret medborgerskabsideal. Der er dog, ifølge Siim, grænser for denne demokratiske udfoldelse, som kan tilskrives kvinders relative fattigdom, marginalisering og familieorientering. Siim tilslutter sig den pluralistiske model, omend hun stadig fastholder forskelle på politisk magt mellem kvinder som gruppe og mænd.

Man kan med stor tydelighed registrere, at artiklen er skrevet 15 år før vi fik en kvindelig statsminister og mange førende kvindelige politikere og tilsvarende før kvinder blev de førende i de veluddannedes rækker. Samtidig er den skrevet før kvindebevægelsen, sammen med de fleste andre politiske bevægelser, led en stille død eller snarere kom til at indgå i forskning og statslig forvaltning. Det var også før begrebet intersektionalitet blev et internationalt anerkendt begreb for sammenstødet mellem forskellige selekterende mekanismer som køn, race, religion og etnicitet. Det betyder til gengæld også, at kvindeperspektivet fortsat spiller en afgørende rolle i artiklen.

Et par år senere bragtes et temanummer om et relateret fænomen, nemlig forholdet mellem velfard, arbejde og omsorg (KKF $1997 / 2$ ). I dette nummer skrev dette essays forfatter et essay (Sjørup 1997), om velfærdsstaten som middel i kvinders magtspil. Dette essay var i nogen grad inspireret af diskussionen med Anne Knudsen om, hvorvidt kvinder indtog en ny position som magtudøvere i det velfærdsstatsregime, hvor jeg med udgangspunkt i Foucaults begreb om governmentality (Foucault 1977) diskuterede, om det vi anså som omsorg snarere kunne betragtes som en veltilrettelagt styring og forventning om selvstyring af borgerne i velfærdsstaten.

I samme temanummer skrev Hanne Marlene Dahl en artikel, hvor hun gennemgår britisk og nordisk omsorgsrationalitet og moraletik, og hvor hun diskuterer, hvorvidt der faktisk eksisterer en særlig omsorgsrationalitet, og om den er særligt knyttet til køn.
Man kan således her se, at den diskussion af forholdet mellem magt, kønskonstruktion og følelser, som i dag omtales som 'den affektive vending' for så vidt allerede var på dagsordenen for 15 år siden, eller måske endnu tidligere, da den norske sociolog Bjørg Åse Sørensen (Sørensen 1982) introducerede ansvarsrationalitetsbegrebet som et modbegreb til Max Webers begreb om teknisk-økonomisk rationalitet.

\section{SUSANNE I STRUTSKØRT OG KORSAGE: AKADEMIAS DRAG}

Den anden artikel i temanummeret om teori (KKF 1994/3), som jeg vil hæfte mig ved, er Dorte Marie Søndergaards artikel "Køn som metaprincip". Denne artikel kan betragtes som et delstudie i forfatterens hovedværk Tegnet på kroppen (Søndergaard 1996), som på mange måder blev skelsæettende i dansk kønsforskning. Den tiltrak en helt ny gruppe af unge kønsforskere og studerende, som formentlig så denne tendens som en ny generations mere akademiske tilgang til køn i forhold til den første kvindeforskergenerations standpunktsfeminisme.

I artiklen tages der udgangspunkt i figuren Susanne, en kvindelig studerende som altid scorer topkarakterer på studiet og som iført strutskørt og korsage kaster sig ud i akademiske diskussioner med lærere og medstuderende. Til festerne er hun tilsvarende opsøgende og seksuelt frembrusende over for de mandlige studerende, og hun træder således ud af de fastlagte normer og handlemuligheder for sit kønsmærke og tiltager sig det andet køns privilegier. Man kan dermed sige, at Susanne performer sit $k ø n$ uden at acceptere de fastlagde normer og diskurser for kønsudtryk.

Søndergaard analyserer fænomenet Susanne ud fra Butler, først fra Gender Trouble (Butler 1990), hvor Butler karakteriserer kønnet som performativt, dvs. at "kønnede identiteter konstitueres gennem de udtryk for køn, som ellers siges at være kønsidentitetens resultat" (Søndergaard 
1994: 50). Derefter gennem Bodies That Matter (Butler 1993), hvor Butler foreslår:

(...) at man i stedet for at tænke performance som en særegen og tilsigtet handling, skal tænke den som en gentagende og citerende praksis, og at det netop er gennem gentagelserne og citaterne, at de effekter produceres, som citaterne almindeligvis antages at navngive (Søndergaard 1994: 50).

Søndergaard konkluderer på analysen, at Susanne optræder som akademias drag: hun forvirrer og fejlciterer, og hun insisterer på at bringe kvindelighedskonnoteret seksualitet i kontakt med mandlighedskonnoteret akademisk kompetence.

Dermed var Søndergaard også med til at konceptualisere det fænomen, at kvindelige studerende i 1990'erne reelt opgav den kvindelighedskonnoterede forventning om, at kvindelige studerende skulle 'holde kxft og være smukke', for at citere Vita Andersens bogtitel fra 1989 (Andersen 1989), og dermed at de stille piger holdt op med at være stille og derfor tilsvarende at drenge kunne ses som trængte.

I forlængelse af netop samme problematik bringes der i samme nummer (KKF 1994/3) to debatindlæg, et af Anne Knudsen (Knudsen 1994b), som hævdede, at drengene blev trængt ud af uddannelsessystemet gennem feminiseringen af samme, og et modindlæg af dette essays forfatter (Sjørup 1994), hvori jeg hævdede, at drengene på ingen måde var trængt ud, selv om der var kommet flere piger, men derimod med statistikker kunne bevidne, at der snarere var tale om, at drengene koncentrerede sig om de tekniske fag, naturvidenskab, militær og politi, mens kvinderne koncentrerede sig i sundhed, prdagogik og humaniora.

Alligevel fik Anne Knudsen stor offentlig opbakning om sine synspunkter, og man kan jo konstatere, at disse synspunkter trives i bedste velgående i dag, og danner baggrund for, at store projekter udbydes, som skal beskæftige sig med de marginaliserede drenge.

\section{QUEER OG TRANS}

Allerede i begyndelsen af 1990'erne opstod det nye begreb 'queer', både som en politisk bevægelse, der forsøger at gøre op med stereotype og entydige kropsmærkninger og akademisk som en ny tendens i kønsforskningen, der langt hen ad vejen også var inspireret af Judith Butler og hendes bidrag til at af-essentialisere kønnet.

Kvinder, Køn \& Forskning har således bragt to temanumre om henholdsvis skæve køn, queer eller trans, nemlig det første i $2003(2003 / 1)$ og det andet i 2011 (2011/3-4). Det er karakteristisk, at dette emne i højere grad er med til at bringe de mandlige forskere på banen end de øvrige.

I 2011s temanummer om trans lægges der afstand til den sammensmeltning af queer og transbegrebet, som jeg også gør mig skyldig i her, idet der i de transkønnedes historie og konstruktion både indgår en form for medicinsk kategorisering og samtidig også en diskussion for og imod operationer, for at komme det oplevede køn nærmere. Imidlertid stod det mig klart på den konference, som i november 2011 blev afholdt på KU for at introducere temanummeret, at der langt hen ad vejen er en frelles inspiration for henholdsvis kønsstudier som sådan, queer- og transstudier, som i høj grad hviler på Butlers arbejde.

Samtidig fremhæver Jan Wickman i sin oversigtsartikel om transstudier i temanummeret, at queerteorien ud fra et sociologisk perspektiv især har været kritiseret for en overdreven tekstualisering og en underudviklet forståelse for det sociale og det empiriske samt de levede erfaringer. Disse er i høj grad for de transkønnede opfattelser af at være født i en forkert krop og samtidig at dette ikke lader sig nærmere bestemme. Ikke desto mindre har queerdebatten medvirket til et mere fleksibelt syn på transpersoner, således at der fx i Finland er indført en 
ny diagnostisk kategori 'transgender' ved siden af 'transseksuel'. Wickman kalder sin artikel "Trans i queerdebatt - Revolutionen som uteblev?", som et udtryk for at de transformerende potentialer, der syntes at være i transdebatten i 1990'erne, er udd $\varnothing$ de, mens diskussionen er fadet ud.

\section{VORES FALLOS}

I henholdsvis 1997 og 1999 udsendte KKF to temanumre, som i fællesskab kunne karakteriseres som maskulinitetsstudier. Det første med den ganske monumentale titel Vores Fallos, der på omslagets forside er prydet med en pigtrådsomslynget oprejst dildo og på bagsiden fire kloner af det samme billede.

Valget af titlen begrundes af temaredaktør Anette Dina Sørensen med, at den er en parafrasering af Carlsbergreklamen 'Vores øl' og dermed polemisk i sit anslag:

Den antyder, at patentet på fallosfortolkninger ikke kun er undsluppet Freuds men også kvindeforskningens greb. I de sidste mange år har andre grupper budt ind med analyser af maskulinitetskonstruktioner. Mandlig seksualitet, magt og faderskab. Bidrag, der medvirker til at ændre billedet af en "fallogocentrisk verden". I dette lys kan forsideillustrationen antyde, at fallos som tegn eller 'stor fortælling' ikke længere er tilstrækkelig, når verden og relationerne mellem kønnene skal fortolkes. Fallos er ikke længere alt, den er ikke længere hverken deres eller vores, men alles. Måske er den derved både intet og ingens hvem ved? (Sørensen 1997: 4).

I samme nummer er tre ud af fire artikler skrevet af mænd, men artiklerne lever ikke op til det opbrud, som indledningen måtte antyde. En af artiklerne er skrevet af svenske Thomas Johansson som i "Det globala gymet. Mandlig og kvinnligt i simulakrats tidsålder" (Johansson 1997) beskæftiger sig med den nye tendens, fitnesscentret, og dets betydning for kvindelige og mandlige kropsidealer. Ifølge artiklen fremhæver det idealet om den hårde muskuløse krop for både kvinder og mænd. På den ene side fremhæves forskellene men på den anden side bliver den body-buildede krop et fælles ideal for det moderne menneske, som selv vil iscenesætte og fremstille sin krop efter tilsyneladende egne idealer.

I det andet temanummer har mandeforskningens australske nestor R.W. Connell (Connell 1999) skrevet en artikel, som tager udgangspunkt i dennes oprindelige teori om hegemoniske maskuliniteter. I denne artikel skriver han om rekonstruktion af maskuliniteter på globalt plan, ikke mindst set i relation til kvinders anderledes rolle, en global tidsalder med flere tværkulturelle møder, men også med en stadig mere omfattende indskrivning af køn i statslige og overstatslige organisationer. Dermed er hegemonien på den ene side blevet udfordret og på den anden side generobret på globalt plan i kraft af at den vestlige form for militarisering og uniformering er blevet udbredt, den transnationale businessman i sit vestlige jakkesæt er blevet rollemodel for internationale politikere og forretningsfolk, og børshandleren er blevet et synonym for den vestlige kapitalismes verdensherredømme.

Efter årtusindeskiftet blev Bob Connell til Raewyn og personificerede dermed sin egen rolle i de køn, som var i opbrud.

\section{AFSLUTNING}

Kvinder, Kon \& Forskning blev fodt i 1990'erne og dermed også efter det store paradigmatiske nybrud, som tog fart i 1980'erne og siden kom til at dominere meget af humanistisk og samfundsvidenskabelig forskning. Dette nybrud blev i første omgang italesat som et postmoderne nybrud og sås i sammenhæng med både kunstens, arkitekturens og landsskabspolitikkens opgør med modernismens dyrkelse af de lange lige linjer og de store projekter, stål og beton, hvor alle forventedes at have 
de samme behov for en teknisk-moderne afvikling af hverdagen og tilsvarende gjorde op med unødvendig pynt og krummelyrer.

Dermed blev det også et opbrud med de store fortællinger, de store frigørelsesfortællinger, marxisme, freudianisme, liberalisme m.m. og i kønsforskningen udfordrede bl.a. Donna Haraway (Haraway 1991) og Sandra Harding (Harding 1991) tilsvarende de store fortællinger og 'Gudetricket', forestillingen om, at videnskaben kunne indtage en guds position og analyse og beskue verden udefra uden egeninteresse eller hildethed med en transcendent tilgang til viden og sandhed. Svaret blev situated knowledge: den erkendelse, at viden kommer et sted fra som erfaret viden, og dermed også indeholder dette særlige udsigtsfelt, det skæublik, som giver de marginaliserede individer en særlig indsigt i de magtfulde diskurser set fra neden og dermed også et særligt potentiale til at bryde disse diskurser.

For kønsforskningen blev det i høj grad Judith Butler, som kom til at indtage en central position i opgøret, dels med de store fortællinger og dels med biologiseringen af køn. Samtidig markerede dette også enden på standpunktsfeminismen og dermed også den sammensmeltning mellem politisk, social- og forskningsmæssig praksis, som eksisterede i kønsforskningens barndom i 1970'erne og 1980'erne.

Dermed blev kønsforskningen også voksen som videnskabsgren, men samtidig også med den fare, at den kunne komme til at sætte en ny sandhed i stedet for de store fortællinger og kollektive fantasier om et fælles frigørelsesprojekt - og vel også langt hen ad vejen har gjort det.

Med til historien hører også det indspark, som i første omgang kom fra de sorte feminister, som ikke kunne acceptere det hvideherrefolks kvinders frigørelsesprojekt som et, de skulle tage til sig. Det blev indledningen til diskussionerne om intersektionalitet, som stadig pågår, men som også har sine store begrænsninger i det stadigt større antal af intersektionaliteter, der må tages ind $\mathrm{i}$ analyserne, hvis der skal tages højde for alle typer af differences, forskelle, modsigelser og modforestillinger.

Derudover blev mændenes modspil også ret hurtigt en udfordring for kønsforskningen, idet mændene jo gjorde krav på også at have et køn og på retten til at skrive dette køns historie som andet end en bøddelrolle i forhold til kvindekønnet. Endelig blev udfordringen fra queer, skæve køn og trans også en udfordring i forhold til at opretholde binariteten mellem kvinder og mænd og til at udfordre de kønsskæbner, som vi alle tror at bære rundt på i kampen for at identificere os med vore køn og etablere en kønnet praksis, som er genkendelig for det pågxldende køn.

Efter min læsning af 20 års Kvinde, Køn o Forskning eller ca. 60 enkeltpublikationer kan jeg konstatere, at tidsskriftet på forbilledlig vis har afspejlet men også udfordret dette overordnede udviklingsforløb fra feministisk standpunktsteori til en langt mere udfoldet og teoretisk funderet kundskabsopbygning i studiet af kønnet i alle dets aspekter.

\section{LITTERATUR}

- Andersen, Vita (1989): Hold kaft og vor smuk. Gyldendal, København.

- Butler, Judith (1990): Gender Trouble: Feminism and the Subversion of Identity. Routledge, New York.

- Butler, Judith (1993): Bodies That Matter: On the Discursive Limits of "Sex". Routledge, New York.

- Connell, R.W. (1999): Masculinities and Globalisation, i: Kvinder, Køn e Forskning 1999/3.

· Fossum, Mikkel Bang (2001): “- men sådan er min kæresten ikke ...” Om mandlige turisters forhold til prostituerede kvinder i et thailandsk feriemål, i: Kvinder, Køn \& Forskning 2001/3.

- Foucault, Michel (1977): Sécurité, Territoire et Population. Cours au Collège de France 1977-1978. Gallimard/Seuil, Paris.

- Haraway, Donna (1991): Simians, Cyborgs, and Women: The Reinvention of Nature. Routledge, New York. 
. Harding, Sandra (1991): Whose Science? Whose Knowledge? Thinking from Women's Lives. Cornell University Press, New York.

- Johansson, Thomas (1997): Det globala gymet. Manligt og kvinnligt I simulakrats tidsålder, i:

Kvinder Kon \& Forskning 1997/4.

- Pilgaard Johnsen, Poul (2005): Det fordømte menneske: Jorgen Leth og den nye sedelighedsfejde. People's Press, København.

- Knudsen, Anne (1994a): Forvandlede kroppe, i: Kvinder, Køn \& Forskning 1994/2.

- Knudsen, Anne (1994b): Kønnet under uddannelse, i: Kvinder, Kon \& Forskning 1994/3.

- Leth, Jørgen (2005): Det uperfekte menneske: scener fra mit liv. Gyldendal, København.

- Lützen, Karin (1994): Jul på sømandsmissionen i Calcutta, i: Kvinder, Køn \& Forskning 1994/4.

- Lykke, Nina \& Bryld, Mette (1995): Delfinprinsesser og ædle vilde, i: Kvinder, Køn \& Forskning $1995 / 2$.

- Lykke, Nina (2008): Kønsforskning. En guide til feministisk teori, metodologi og skrift. Samfundslitteratur, Frederiksberg.

- Sjørup, Karen (1994): Svar til Anne Knudsen, i: Kvinder, Køn \& Forskning 1994/3.
- Sjørup, Karen (1997): Velfærdsstaten som middel i kvinders magtspil, i: Kvinder, Køn \& Forskning $1997 / 2$.

- Siim, Birte (1994): Køn, medborgerskab og magt, i: Kvinder, Køn \& Forskning 1994/3.

- Søndergaard, Dorte Marie (1994): Køn som metaprincip, i: Kvinder, Køn \& Forskning 1994/3

- Søndergaard, Dorte Marie (1996): Tegnet på kroppen. Køn: Koder og konstruktioner blandt unge voksne $i$ Akademia. Museum Tusculanum, København.

- Sørensen, Anette Dina (1997): Indledning til vores fallos, i: Kvinder, Køn \& Forskning 1997/4.

- Sørensen, Bjørg Åse (1982): Ansvarsrasjonalitet, i: H. Holter (red.): Kvinner i fellesskap. Universitetsforlaget, Oslo.

- Warring, Anette (1994): Kvinders kroppe, i:

Kvinder, Køn \& Forskning 1994/2.

- Wickman, Jan (2011): Trans i queerdebatt - Revolutionen som uteblev? i: Kvinder, Køn \& Forshning 2011/3-4.

Karen Sjørup, lektor

Institut for Samfund og Globalisering

Roskilde Universitet 